\title{
ANALISIS FRAMING PEMBERITAAN PIDATO MENTERI NADIEM MAKARIM PADA PERINGATAN HARI GURU NASIONAL
}

\author{
Nove Kurniati Sari \\ Universitas Islam Negeri Sunan Kalijaga Yogyakarta \\ noveophe@gmail.com
}

\begin{abstract}
Abstrak
Nadiem Makarim merupakan bagian dari kabinet Jokowi yang mendapat respon pro-kontra dari masyarakat. Latar belakangnya sebagai pebisnis dikritik berbagai pihak yang meragukan kapasitasnya dalam pemerintahan. Kritik terhadap Nadiem juga diberikan pada teks pidatonya pada Hari Guru yang dinilai berbeda dari pidato hari besar lainnya. Metode dalam penelitian ini menggunakan analisis framing model Robert $N$. Entman untuk mendalami sudut pandang media online terhadap teks pidato Nadiem Makarim. Penulis berargumen, dengan menggunakan analisis framing, konstruksi peristiwa yang disajikan media dapat dipahami dari berbagai sudut pandang dan melahirkan penafsiran publik seobjektif mungkin. Tujuan penelitian ini adalah untuk menemukan perbedaan antar media dalam mengolah dan menyajikan fakta atas suatu peristiwa. Hasil penelitian ini menunjukkan bahwa setiap media memiliki ciri khas masing-masing dalam memberitakan pidato Hari Guru oleh Nadiem Makarim. Liputan6 menyajikan pemberitaan dengan sudut pandang keprihatinan Nadiem terhadap pendidikan nasional. Sedangkan Pontas.id, Republika.co.id, dan CNNIndonesia.com menggunakan sudut pendang tokoh pendidikan dalam mengkritisisasi aspek penerapan dan prospek dari esensi naskah pidato tersebut.
\end{abstract}

Kata kunci:

framing, media massa, Nadiem Makarim

\begin{abstract}
Nadiem Makarim is part of the Jokowi cabinet which received pros and cons responses from the public. His background as a businessman has been criticized by various parties who doubt his capacity in government. Criticism of Nadiem was also given in the text of his speech on Teacher's Day which was considered different from other formal public speeches. The method in this study uses Robert N. Entman's framing analysis model to explore the perspective of online media on Nadiem Makarim's speech text. The author argues, using framing analysis, the construction of events presented by the media can be understood from various points of view and lead public interpretations as objectively as possible. The purpose of this study is to find differences between the media in processing and presenting facts about an event. The results of this study indicate that each media has its own characteristics in preaching the Teacher's Day speech by Nadiem Makarim. Liputan6 presents the news from the standpoint of Nadiem's concern for national education. Whereas Pontas.id, Republika.co.id, and CNNIndonesia.com use the perspective of educational leaders in criticizing aspects of the application and prospects of the essence of the speech text.
\end{abstract}

Keywords:

framing, mass media, Nadiem Makarim

\section{PENDAHULUAN}

Media massa di era globalisasi ini tidak hanya terbatas pada ranah industri pemberitaan saja, namun telah merambah dunia politik dan pemerintahan. Fenomena keterlibatan media dalam dinamika persaingan politik sudah menjadi 
rahasia umum di masyarakat. Bisa dikatakan pula bahwa dalam beberapa kasus, media massa gagal menjalankan fungsi kenetralannya dalam menyajikan pemberitaan kepada masyarakat. Sehingga pemberitaan yang beredar terlihat memihak dan berusaha memunculkan isu-isu demi keuntungan suatu golongan.

Permasalahan keberpihakan media massa diperparah kurangnya keterampilan masyarakat dalam menilai pemberitaan yang kredibel dan dapat dipercaya keakuratannya. Sehingga hal ini berdampak kepada mudahnya pihak tertentu untuk terprovokasi oleh pemberitaan yang belum bisa dibuktikan kebenarannya. Karena seringkali di dalam menilai informasi yang didapat, masyarakat lebih mengutamakan selera politik dibanding proses konstruksi mendalam terhadap realitas yang sesungguhnya.

Realitas dalam media adalah bentuk dari kontruksi kejadian-kejadian yang melalui proses seleksi. Realitas yang disampaikan oleh media seringkali berbeda dengan realitas lapangan yang sesungguhnya. Format penyajiannya pun mengandung pandangan serta ideologi dari pihak media itu sendiri. Sehingga setiap pemberitaan yang ada, merupakan hasil pandangan subjektif dari jurnalis atau media massa itu sendiri. Sudut pandang dan pikiran dari wartawan selalu mengambil bagian penting dalam berita yang ada di media. Artinya, sebuah berita merupakan produk olahan paradigma, ideologi, bahkan kepentingan pihak tertentu baik media itu sendiri maupun pihak lainnya.

Negara Indonesia pada tahun 2019 merupakan tahun pelantikan Presiden Joko Widodo dalam periode kedua pemerintahannya, sekaligus Jajaran Menteri Kabinet Indonesia Maju untuk masa pemerintahan 2019-2024. Reaksi masyarakat atas susunan kabinet baru dibawah komando Presiden Joko Widodo ini menuai reaksi beragam baik dari pemerhati politik maupun masyarakat umum. Bersamaan dengan jajaran menteri lain, Nadiem Makarim dilantik oleh presiden Joko Widodo sebagai Menteri Pendidikan dan Kebudayaan periode Pemerintahan 2019-2024. Sejak awal pelantikannya, banyak perbincangan seputar kapabilitas dan apakah ia akan sanggup menjalankan tampuk pemerintahan sesuai keinginan masyarakat. Rekam jejaknya dan relevansi dengan jabatannya saat ini juga mengundang banyak pertanyaan. Namun selayaknya pemimpin yang baik, Nadiem Makarim tidak menunjukkan sikap antipati atau negatif terhadap perbincangan seputar dirinya di masyarakat.

Pada peringatan Hari Guru Nasional yang jatuh pada tanggal 25 November 2019, Nadiem Makarim menuliskan naskah pidato sambutan yang dibacakan di setiap upacara Hari Guru Nasional di sekolah-sekolah dan perguruan tinggi di Indonesia. Media massa berlomba-lomba mengemas pemberitaan seputar teks pidato Nadiem tersebut. Dengan berbagai cara dan sudut pandang, media menyajikan "bentuk" penafsiran baru dari teks pidato Menteri Pendidikan tersebut. Pemberitaan yang beragam seputar sebuah teks pidato merupakan sebuah fenomena menarik yang perlu diperhatikan secara seksama.

Masyarakat tentunya dapat membaca sendiri secara langsung dan memaknai teks pidato tersebut. Namun media membingkainya dengan pernak-pernik kata yang membuat masyarakat memiliki multitafsir tehadap teks pidato yang berjumlah dua lembar tersebut. Dinamika ini menarik untuk didalami menggunakan model analisis Framing Robert N. Entman seputar pemberitaan teks pidato Hari Guru Nasional Nadiem Makarim 25 November 2019 yang diberitakan di portal berita online 
Indonesia. Melalui proses analisis ini, peneliti ingin mengkaji sudut pandang politik media tersebut terhadap fenomena teks pidato ini.

Model Analisis Framing Robert N. Entman menghasilkan rumusan masalah penelitian ini sebagai berikut (1) bagaimana pendefinisian masalah (define problems) berita teks pidato Hari Guru Nasional oleh Nadiem Makarim selaku Menteri Pendidikan dan Kebudayaan?; (2) bagaimana perkiraan masalah (diagnose causes) berita teks pidato Hari Guru Nasional oleh Nadiem Makarim selaku Menteri Pendidikan dan Kebudayaan?; (3) bagaimana keputusan moral (Make moral judgement) berita teks pidato Hari Guru Nasional oleh Nadiem Makarim selaku Menteri Pendidikan dan Kebudayaan?; (4) bagaimana rekomendasi penyelesaian (Treatment recommendation) berita teks pidato Hari Guru Nasional oleh Nadiem Makarim selaku Menteri Pendidikan dan Kebudayaan?

\section{KONSEP ANALISIS FRAMING}

Framing merupakan cara media menyajikan sebuah peristiwa, dengan penekanan dan penonjolan pada permasalahan tertentu dari sebuah kejadian. Proses penonjolan aspek tertentu ini membuat peristiwa tertentu lebih berkesan dan mudah diingat oleh publik. Framing menurut Frank D. Durham membuat realitas dunia yang rumit menjadi sederhana dan dapat dimengerti. Secara subjektif, realitas sosial merupakan kondisi dinamis dan mudah berubah dalam keseharian kehidupan dan interaksi manusia (Mulyana 2006).

Proses analisa teks media dapat dilakukakan dengan beberapa pendekatan model framing, salah satunya model milik Robert N. Entman yang digunakan dalam artikel ini. Persepsi kita tentang realita atau dunia menurutnya sangat dipengaruhi oleh proses penafsiran dan pembingkaian yang dilakukan terhadap realita tersebut. Entman menegaskan terdapat dua dimensi pokok dalam proses framing realita yaitu seleksi isu dan penekanan sebuah aspek dari suatu isu/realita. Framing media terjadi setelah proses seleksi dari beberapa isu kemudian memilih salah satunya untuk dikemas. Dengan kata lain, framing adalah proses mengetahui perspektif seorang jurnalis/wartawan saat proses seleksi isu dan menulis suatu berita (Eriyanto 2011).

Terdapat empat elemen dalam proses framing Robert N. Entman yaitu: Define Problems, yaitu penjabaran perspektif suatu peristiwa. Diagnose Causes, yaitu perkiraan sumber permasalahan. Make Moral Judgement, yaitu penilaian moral yag dipaparkan dalam berita. Kemudian terakhir Treatment Recommendation, yaitu penawaran solusi demi menyelesaikan konflik yang ada (Eriyanto 2002).

Media dan Berita dalam Perspektif Konstruksionis

Konstruksi realita merupakan proses kompleks dimana media memiliki peran yang sangat strategis. Proses konstruksi realitas ini terbentuk dari paradigma wartawan terhadap realita, serta dinamika politik tempat media tersebut berada. Mekanisme kinerja media massa yang dipengaruhi oleh sistem politik sebuah negara juga turut andil dalam proses rekonstruksi ini (Hamad 1999). Sebuah konflik dapat dipertajam sekaligus dikaburkan oleh media. Selain itu realita juga dapat dikonstruksi, namun hiperrealitas juga dapat muncul dari proses konstruksi tersebut. Jika hiperrealitas terjadi, maka publik bisa saja mempercayai sesuatu yang hanyalah hasil dramatisasi dan tidak bisa dibuktikan kebenarannya (Sobur 2009). Dramatisasi oleh media merupakan hal negatif yang perlu dihindari karena bersifat provokatif dan memperkeruh keadaan bagi pihak yang bertikai. 
Fakta dilapangan yang terjadi adalah masyarakat awam mempercayai sepenuhnya pemberitaan media massa yang beredar. Pemberitaan tersebut dianggap sebagai sebuah kebenaran atas persoalan yang terjadi. Seharusnya, dilakukan proses telaah mendalam dan seleksi terhadap pemberitaan. Ini perlu dilakukan karena media massa seringkali memuat kepentingan dan keberpihakan yang dapat menggiring persepsi publik untuk keuntungan pihak tertentu. Walaupun secara garis besar, seluruh media memiliki hak prerogatif dalam mekanisme pemberitaan sesuai dengan keinginan media itu sendiri.

Berita dapat dikatakan sebagai buah dari kinerja kumpulan individu dalam media yang muncul berdasarkan pertimbangan dan ideologi yang ada di lingkungan. Berita tersebut berisi fakta atau realitas yang dikemas dan disajikan ke khalayak ramai baik melalui elektronik maupun cetak. Berita merupakan laporan dari suatu realita yang ada di masyarakat, yang diolah dan direkonstruksi oleh media dengan dipengaruhi paradigma serta pemahaman dari wartawan atau jurnalis pada media massa itu sendiri.

Proses pemahaman dipengaruhi sudut pandang dan penilaian tertentu sehingga akan bersifat subjektif dan bukan pencerminan utuh dari sebuah kejadian (Eriyanto 2011). Wartawan/jurnalis memiliki peranan aktif dalam mengemas kejadian sesuai dengan sudut pandangnya. Sehingga dapat dikatakan bahwa realita bukanlah materi yang sudah ada dilapangan yang kemudian diliput oleh jurnalis begitu saja. Realita dalam media adalah sebuah produk baru hasil olahan paradigma media yang tidak lain merupakan hasil rekonstruksi kejadian dalam bentuk narasi (Barata dalam Birowo 2004).

\section{Jurnalis dan Media dalam Perspektif Politik dan Kekuasaan}

Kekuasaan merupakan sebuah aspek yang memerlukan instrumen kontrol. Jurnalis merupakan salah satu instrumen pengontrol tersebut. Sistem kontrol oleh jurnalis berbentuk kritik dan penyampaian aspirasi yang tercermin dalam pemberitaan di media massa. Pemberitaan yang ada di media massa juga berperan dalam mengawasi dan mereduksi kewenang-wenangan dan praktek tirani dalam kehidupan bermasyarakat. Selain itu jurnalis dan media massa berperan sebagai pengawas bagi pemegang kekuasaan untuk tidak melakukan praktek-praktek yang merugikan publik, serta sebagai sarana penyuara aspirasi masyarakat yang dapat berdampak dalam perumusan kebijakan publik dalam pemerintahan (Kovach and Rosenstiel 2001)

Dinamika perkembangan media massa selalu berbanding lurus dengan ritme politik sebuah negara. Sebagai contoh konkrit adalah jika sebuah negara sedang dalam transisi politik, maka secara otomatis media massa menjadi agen pemerintaha baru dalam meyuarakan agenda reformasinya kepada masyarakat (Wahyuni 2007). Dalam masa transisi politik, media memegang peranan sebagai medium dan pendorong proses demokratisasi yang sedang berjalan (Humphreys and Lang 1998). Namun permasalahan yang kerap kali muncul adalah monopoli oleh elit politik tertentu terhadap media massa, yang berdampak terhadap ketidakseimbangan kekuatan propaganda (Kurnia 2015). Ini merupakan sebuah praktek penyalahgunaan kekuasaan yang kerap kali terlihat dalam media massa. Media massa sebagai agen strategis publik disalahgunakan dalam upaya menggalang pendukung. 
Politik media adalah sebuah sistem yang menggunakan aspek komunikasi media sebagai alat menjangkau masyarakat (Aminah 2006) Dalam politik media, terdapat tiga pelaku utama yaitu politisi, jurnalis, dan kelompok kepentingan/masyarakat. Politisi menggunakan politik media untuk mobilisasi publik dan meraih dukungan untuk memenangkan kompetisi dalam pemilihan umum. Jurnalis menggunakan politik media untuk menghasilkan pemberitaan yang menarik dan menyuarakan independensi suara serta signifikansi jurnalismenya. Sedangkan masyarakat menggunakan politik media untuk mengawasi pemegang kekuasaan dan menjaga pemerintahan tetap akuntabel. Ketiga aktor politik media tersebut saling mempengaruhi. Politisi berkepentingan untuk mengontrol isi berita politik, sementara jurnalis berkepentingan untuk menunjukkan independensinya dan mendapat perhatian publik dalam pasar media yang kompetititf, serta masyarakat secara konstan membutuhkan pemberitaan yang kredibel mengenai pemerintahan yang berjalan dan edukasi tentang politik pemerintahan demi mewujudkan kehidupan demokrasi yang selaras (Rothman and Lichter 1982).

\section{METODE PENELITIAN}

Sumber data dalam penelitian ini adalah sumber data primer diperoleh dari proses dokumentasi pemberitaan pidato Hari Guru Nasional Nadiem Makarim pada situs Liputan6.com, Pontas.id, Republika.com, dan CNNIndonesia.com yang terbit 23 25 November 2019. Sedangkan data sekunder bersumber dari literatur buku, karya ilmiah, jurnal, maupun internet yang relevan dengan penelitian (Sugiyono 2010).

Artikel ini menggunakan model analisis framing dari Robert E. Entman. Konsep mendasar dalam model ini menelaah sebuah wacana kemudian menjabarkan, menjelaskan, menilai dan mengevaluasi, dan merekomendasi opsi lain atas wacana tersebut. Obyek penelitian ini adalah pemberitaan seputar pidato Hari Guru Nasional yang diberikan oleh Nadiem Makarim selaku Menteri Pendidikan dan Kebudayaan periode 2019-2024. Portal berita yang dipilih Liputan6.com, Pontas.id, Republika.com, dan CNNIndonesia.com. Portal berita online tersebut penulis pilih karena berskala nasional, dan memiliki statistik pengunjung situs yang terbilang lebih banyak dibanding situs berita lainnya.

\section{HASIL ANALISIS FRAMING PEMBERITAAN}

Penelitian ini menggunakan analisis model framing Robert N. Entman dimana didalamnya terdapat empat elemen yaitu: Define Problems, yaitu penjabaran perspektif suatu peristiwa. Diagnose Causes, yaitu perkiraan sumber permasalahan. Make Moral Judgement, yaitu penilaian moral yag dipaparkan dalam berita. Kemudian terakhir Treatment Recommendation, yaitu penawaran solusi demi menyelesaikan konflik yang ada (Eriyanto 2002). Berdasarkan empat elemen ini, peneliti akan menganalisis berita di media, kemudian hasil analisis tersebut akan dinterpretasi untuk menemukan bagaimana portal berita Liputan6.com, Pontas.id, Republika.com, dan CNNIndonesia.com membingkai informasi dan memberitakannya. 


\section{Cerita Viralnya Naskah Pidato Nadiem Makarim (Anugrahadi 2019)}

Define Problems, Nadiem Makarim menyatakan sumber inspirasi dari teks pidato bersumber dari pemikiran dan pendapatnya sesuai konteks jabatan yang dimilikinya. Nadiem juga menegaskan bahwa ia berusaha melihat permasalahan dari sudut pandang guru-guru seluruh Indonesia. Berikut kutipannya:

"Nadiem mengatakan, dirinya merangkai kata-kata dengan penuh ketakutan. Menurut dia, kalimat yang ditulisnya adalah opini pribadi tapi dalam kapasitas Menteri Pendidikan dan Kebudayaan"

Dalam pemberitaan ini, wartawan berusaha menyajikan kronologi dan latar belakang penulisan isi teks pidato oleh Menteri Pendidikan dan Kebudayaan tersebut. Isi berita ini menyampaikan pernyataan langsung Nadiem Makarim pada Konferensi Pendidikan Indonesia pada 30 November 2019 terkait keprihatinannya pada kondisi pendidikan di Indonesia.

Diagnose Causes, Liputan 6 memandang bahwa permasalahan bermula pada guru yang dibebani tugas-tugas diluar mendidik murid, yang mengalihkan guru dari tanggungjawab sesungguhnya sebagai pendidik:

"Nadiem dalam pidatonya juga menyebut bahwa para guru sangat ingin membantu murid-murid yang mengalami ketertinggalan di kelas. Namun, apa daya, waktu sang guru habis terbuang mengerjakan tugas administratif tanpa manfaat yang jelas"

Make Moral Judgement, Nadiem Makarim menegaskan agar inovasi di kalangan guru dimulai secara mandiri tanpa perlu diberi arahan oleh pemerintah:

"Nadiem mengetahui bahwa guru ingin berinovasi. Namun, sulit dilakukan oleh para guru. Untuk itu, dirinya ingin agar para guru mulai berinovasi tanpa harus menunggu perintah"

Treatment Recommendation, Nadiem menghimbau guru untuk tidak terpaku pada peraturan untuk memulai perubahan dalam proses belajarmengajar. Tanggung jawab perubahan adalah tanggung jawab bersama. Perubahan sekecil apapun, akan berdampak pada dinamika pendidikan secara keseluruhan jika dilakukan dengan kontinu.

"Nadiem menekankan bahwa memperbaiki pendidikan menjadi tanggung jawab bersama. "Apa pun perubahan kecil itu, jika setiap guru melakukannya secara serentak, kapal besar bernama Indonesia ini pasti akan bergerak," tandas Nadiem"

Pemberitaan "Cerita Viralnya Naskah Pidato Nadiem Makarim" pada portal berita Liputan 6 menunjukkan bahwa arah pemberitaan digiring kepada pemahaman konteks yang melatarbelakangi penulisan naskah pidato serta pendapat dan opini Nadiem Makarim tentang permasalahan pendidikan di Indonesia. Permasalahan pendidikan yang kompleks memerlukan kerjasama berbagai pihak untuk melakukan perubahan dan solusi. Dari penjelasan di atas dapat dipahami bahwa Liputan 6 mengemas isi berita sesuai dengan apa yang disampaikan oleh Nadiem Makarim sendiri tentang alasan dibalik naskah pidato Hari Guru, yang disampaikan dalam forum resmi Konferensi Pendidikan Nasional. 
Pemberitaan di sebuah media massa telah melalui proses seleksi untuk menentukan peristiwa mana yang dapat diliput oleh seorang jurnalis beserta paradigma yang harus dipergunakan dalam meninjau berita tersebut. Proses seleksi yang terjadi di lapangan dan selanjutnya diberitakan oleh wartawan memiliki latar belakang agenda politik serta ideologi. Dengan begitu, media dapat dikategorikan sebagai subjek konstruksi atas realita, yang berisi bias, keberpihakan, dan pandangan kelompok tertentu (Eriyanto 2002).

2. Pidato Nadiem di Hari Guru, DPR: Semoga Programnya Bisa di Follow Up (Herdian 2019)

Define Problems, Bramantyo Suwondo selaku anggota DPR RI komisi X menilai pidato Nadiem Makarim menyiratkan pemahaman terhadap masalah krusial pendidikan Nasional.

"Bramantyo Suwondo menilai pidato Mendikbud, Nadiem Makarim yang sederhana dan terlihat sudah mengenal beberapa masalah fundamental di pendidikan nasional"

Diagnose Causes, keprihatinan terhadap tragedi yang terjadi pada pendidikan di Indonesia sebagai salah satu bentuk pembiaran oleh pejabat berwenang terhadap ketidaklayakan sarana prasaran pendidikan.

"Situasi semisal ada di Jawa Timur kemarin amat disayangkan seorang Guru meninggal dunia saat menjalankan profesinya dikarenakan sekolah yang rubuh," kata Bramantyo"

Make Moral Judgement, Pontas mencatut pernyataan Bramantyo tentang pentingnya tindak lanjut atas pidato Nadiem Makarim pada Hari Guru tersebut ke dalam tindakan nyata yang dapat dirasakan dampaknya oleh publik.

"Saya harapkan, Nadiem bisa memfollow up pidatonya itu dengan program-program maupun rencana kerja mendukung peningkatan sistem pendidikan kita, dimulai dengan pemenuhan dasar sarana prasarana pendidikan ruang kelas yang baik, fasilitas sekolah yang bagus"

Treatment Recommendation, Bramantyo Suwondo menegaskan bahwa kebijakan-kebijakan diluar aspek administrasi dapat mendatangkan dampak positif terhadap kualitas SDM

"Bilamana Nadiem bisa sukses menciptakan kebijakan-kebijakan yang mendukung profesi guru agar lebih baik pasti anak-anak yang dididik oleh guru-guru kita akan menjadi SDM yang unggul, memiliki karakter, keilmuan dan kesadaran akan manusia lain dan lingkungan"

Pontas Id menyusun struktur berita ke dalam format cara pandang narasumber terhadap tindak lanjut pidato Nadiem Makarim pada Hari Guru Nasional. Follow up yang tepat dan eksekusi kebijakan yang optimal adalah langkah yang perlu ditinjau dan dipertimbangkan secara seksama.

3. PGRI Tanggapi Pidato Nadiem Makarim Sebagai Mendikbud (Dwinanda 2019)

Define Problems, Pengurus Besar PGRI Indonesia melalui Ketua Umumnya Unifah Rosyidi menyatakan bahwa teks-teks pidato tidak dibutuhkan oleh guru, melainkan yang dibutuhkan adalah sudut pandang yang komprehensif pada profesi guru serta suatu tidakan nyata dari pemerintahan. 
"Guru saat ini tidak bisa hanya dipidatokan bahwa guru itu sangat mulia, sangat penting. Itu tidak butuh seperti itu, apa yang dibutuhkan guru adalah kebijakan yang nyata karena kita kekurangan guru," ucap Unifah di Jakarta, Senin"

Diagnose Causes, kurangnya tenaga guru merupakan salah satu permasalahan yang telah ada pada 10 tahun terakhir. Selain itu keprihatinan pada kesejahteraan guru swasta dan honorer menambah panjang daftar problematika pendidikan di Indonesia. Republika mengutip pernyataan Ketua Umum PGRI Indonesia:

"Kita memang tidak boleh selalu ngomong tentang gaji, tapi professionalisme itu melekat di dalamnya, kesejahteraan yang layak. Hal itu dikarenakan para guru adalah orang yang menciptakan, membayangkan masa depan"

Make Moral Judgement, permasalahan pendidikan yang dinyatakan oleh Menteri Pendidikan dan Kebudayaan RI Nadiem Makarim telah menjadi bagian dari program kerja PGRI. Salah satu poin yang diupayakan adalah kemerdekaan guru yang dapat diwujudkan dengan pengurangan aturan-aturan liberatif tentang jam kerja guru.

"Guru katanya harus merdeka, supaya merdeka dikurangi dong dikurangi aturan-aturannya. Akan tetapi nyatanya satu contoh kebijakan, yaitu guru harus melakukan fingerprint sehari tiga kali pagi, siang dan sore. Kalau seperti ini, di mana kemerdekaannya"

Treatment Recommendation, solusi atas permasalahan disajikan oleh Republika dalam kutipan pernyataan Ketua Umum PGRI yang mengatakan bahwa permasalahan tidak akan selesai hanya dengan retorika dan teks pidato saja. Terwujudnya penyederhanaan birokrasi dan otonomi sekolah membutuhkan upaya nyata dalam bentuk pengurangan aturan-aturan yang mempersulit guru.

"Unifah berharap apa yang disampaikan oleh Mendikbud tak hanya menjadi gagasan, melainkan harus ada upaya nyata. Sejumlah aturan yang menghambat guru diminta untuk dipangkas".

Pemberitaan "PGRI Tanggapi Pidato Nadiem Makarim Sebagai Mendikbud" pada portal berita Republika menunjukkan bahwa permasalahan yang disebutkan oleh Nadiem Makarim dalam pidato Hari Guru-nya telah disadari sejak lama oleh organisasi PGRI. Ketua Umum PGRI menyatakan bahwa permasalahan-permasalahan selalu dalam proses berkesinambungan untuk diselesaikan secara tuntas oleh organisasi tersebut. Dengan kata lain, republika menginterpretasikan poin-poin permasalahan pendidikan yang diangkat Nadiem Makarim dalam naskah pidatonya berdasarkan sudut pandang seorang Ketua Umum Pengurus Besar PGRI yang telah menghadapi permasalahan serupa selama masa jabatannya.

Paradigma Republika dalam pemberitaan ini menonjol pada opini dari tokoh PGRI terhadap poin-poin yang ditegaskan Nadiem Makarim dalam naskah pidatonya. Penonjolan opini tokoh seperti ini membuat obyektifitas sebuah informasi mengalami meningkat. Sebuah realita tertentu yang disajikan lebih menonjol dapat mempengaruhi persepsi publik yang membaca media massa 
tersebut. Strategi wacana dengan pemilihan aspek-aspek yang mencolok secara tidak langsung telah memunculkan opini tersendiri di masyarakat.

4. Pengamat: Pidato Nadiem Sulit Dijalankan Guru di Daerah (Charismiadji 2019)

Define Problems, Pemerhati pendidikan Indra Charismiadji menyatakan bahwa proses penerapan arahan pidato Hari Guru Nadiem Makarim dapat menemui kesulitan. Kesulitan tersebut antara lain budaya birokrasi yang telah terbentuk sejak lama.

"Indra mengingatkan Nadiem bahwa urusan administrasi di daerah di luar Jakarta lebih rumit. Dia berkata para guru akan berhadapan dengan budaya birokrasi yang selama ini sudah terbentuk"

Diagnose Causes, aspek utama penyebab rumitnya proses birokrasi yang dihadapi guru, adalah arahan administratif yang bersumber dari kepala dinas dan kepala daerah. Situasi tersebut adalah kerumitan yang sulit dihindari oleh para guru.

"Tantangan terberat bagi guru dalam menjalankan arahan Mendikbud, karena mereka menghadapi atasan mereka yang sayangnya bukan Mas Menteri melainkan kepala daerah"

Make Moral Judgement, CNN Indonesia menegaskan perlunya rencana strategis yang menyentuh lembaga-lembaga terkecil pendidikan baik di daerah maupun di pusat. Rencana strategis tersebut memerlukan kolaborasi berbagai pihak.

"Pelaksanaan solusi tersebut pun harus berupa kolaborasi bersama bukan hanya satu atau dua pihak saja. Kemendikbud dapat ditunjuk presiden sebagai sektor yang memimpin, tapi implementasi harus kolaborasi dan tidak terbatas anggaran masing-masing"

Treatment Recommendation, permasalahan pendidikan di Indonesia tidak terpaku pada aspek kerumitan administrasi saja, namun permasalahan kekurangan tenaga guru di daerah serta kesejahteraan guru.

"Selain masalah administrasi, Indra mengatakan masih banyak masalah dalam dunia pendidikan"

Pendekatan framing model Robert N. Entman dalam pemberitaan "Pengamat: Pidato Nadiem Sulit Dijalankan Guru di Daerah" menegaskan bahwa CNN Indoesia berusaha menunjukkan sudut pandang baru melalui pernyataan pengamat pendidikan. CNN Indonesia menampilkan realitas di lapangan tentang birokrasi seperti apa yang dihadapi guru jika mendapat aturan yang berasal dari pemerintah daerah atau dinas. Dari sini dapat disimpulkan bahwa esensi pidato Nadiem Makarim dan proses penerapannya memiliki permasalahan kompleks dan membutuhkan strategi khusus untuk mengubah paradigma birokrasi yang telah terbentuk lama.

\section{KESIMPULAN}

Pemberitaan yang dilakukan Liputan6.com, Pontas.id, Republika.com, dan CNNIndonesia.com terkait naskah pidato Menteri Pendidikan dan Kebudayaan Nadiem Makarim memiliki ciri khas masing-masing. Liputan6.com memberitakan permasalahan dari sudut latar belakang keprihatinan Menteri Nadiem Makarim 
terhadap pendidikan di Indonesia. Sementara Pontas.id, Republika.com, dan CNNIndonesia.com menyajikan pemberitaan dengan perantara pendapat tokoh organisasi pendidikan atau pengamat pendidikan. Hal ini menyebabkan munculnya kritik dan saran-saran dari tokoh tersebut yang secara lugas ditampilkan dan dibahas dalam ketiga artikel pemberitaan di atas.

Keempat media pemberitaan online dalam penelitian ini memiliki kecenderungan pemberitaan citra yang positif tentang Nadiem Makarim selaku Menteri Pendidikan dan Kebudayaan yang belum lama dilantik dan pernah sukses membawa Gojek menjadi perusahaan yang berkembang pesat. Namun keempat portal berita tersebut memiliki kesamaan dalam hal menampillkan pendapat aktivis pendidikan lain sebagai faktor pembanding dan penafsir dari makna teks pidato pada Hari Guru tersebut. Dengan kata lain, terlihat aspek penegasan bahwa berita yang disajikan bersumber dari tokoh yang kredibel dalam memaknai konteks pendidikan dan bukanlah interpretasi dangkal dari jurnalis semata.

Saran dari penulis adalah pemberitaan seputar sebuah teks pidato adalah sebuah perkara yang bergantung kepada persepsi. Aspek persepsi adalah sesuatu yang bersifat personal dan bebas. Setiap orang punya hak prerogatif untuk menafsirkan teks pidato Nadiem Makarim sesuai sudut pandangnya. Dan portal media sebagai agen pemberitaan seharusnya tidak memihak atau mendramatisir pemberitaan apapun yang ada di masyarakat. Teks pidato Nadiem Makarim ini adalah salah satu contoh wacana yang menurut penulis mendapatkan banyak kritikan yang kurang tepat. Sehingga media massa mengemban tugas utama dalam mentralisir potensi isu yang tidak penting mengenai teks pidato Nadiem Makarim tersebut.

\section{REFERENSI}

Aminah, Siti. 2006. "Politik Media, Demokrasi Dan Media Politik." Masyarakat, Kebudayaan dan Politik 19(3): 35-46.

Anugrahadi, Adi. 2019. "Cerita Viralnya Naskah Pidato Nadiem Makarim." Liputan6.com. https://www.liputan6.com/news/read/4123344/cerita-viralnyanaskah-pidato-nadiem-makarim (January 15, 2019).

Barata, Atep Adya. 2004. "Dasar-Dasar Pelayanan Prima." In Metode Penelitian Komunikasi, Teori Dan Aplikasi, Yogyakarta: Gitanyali.

Burngin, Burhan. 2008. Konstruksi Sosial Media Massa. Jakarta: Kencana Prenada Group.

Charismiadji, Indra. 2019. "Pengamat: Pidato Nadiem Sulit Dijalankan Guru di Daerah."https://www.cnnindonesia.com.https://www.cnnindonesia.com/nasional/ 20191124180948-20-451067/pengamat-pidato-nadiem-sulit-dijalankan-guru-didaerah (December 12, 2019).

Dwinanda, Reiny. 2019. "PGRI Tanggapi Pidato Nadiem Makarim Sebagai Mendikbud." Republika.co.id. https://republika.co.id/berita/q1iunl414/pgritanggapi-pidato-nadiem-makarim-sebagai-mendikbud (January 15, 2019).

Eriyanto. 2002. Analisis Framing: Konstruksi, Ideologi, Dan Politik Media. Yogyakarta: LKIS Group.

- 2011. Analisis Framing: Konstruksi Ideologi, Dan Politik Media. Yogyakarta: LKIS.

Hamad, Ibnu. 1999. "Media Massa Dan Konstruksi Realitas." Jurnal Pantau. ISA/ 6: 
55.

Herdian, Luki. 2019. "Pidato Nadiem Di Hari Guru, DPR: Semoga Programnya Bisa Di Follow Up." https://pontas.id/2019/11/25/pidato-nadiem-di-hari-guru-dprsemoga-programnya-bisa-di-follow-up/ (January 15, 2019).

Humphreys, Peter, and Mathias Lang. 1998. "Pluralism and German Broadcasting: The Symbolic Re-Regulation of German Media Ownership." EPRU Paper No.4: 98.

Kovach, Bill, and Tom Rosenstiel. 2001. The Elements of Jurnalism: What Newspeople Should Know and the Public Should Expect. New York: Crown Publisher.

Kurnia, Dedi. 2015. Komunikasi CSR Politik. Jakarta: Kencana Prenada Media Group.

Mulyana, Deddy. 2006. Metodologi Penelitian Kualitatif. Bandung: PT. Remaja Rosdakarya.

Rothman, S., and S. R Lichter. 1982. "Media and Business Elites: Two Classes in Conflict?" The Public Interest 69: 117.

Sobur, Alex. 2009. Analisis Teks Media: Suatu Pengantar Analisis Wacana, Analisis Semiotika, Dan Analisis Framing. Bandung: PT Remaja Rosdakarya.

Sugiyono. 2010. Metode Penelitian Pendidikan Kuantitatif, Kualitatif Dan R\& D. Bandung: Alfabeta.

Wahyuni, Hermin Indah. 2007. "Politik Media Dalam Transisi Politik: Dari Kontrol Negara Menuju Self-Regulation Mechanism.” Jurnal IImu Komunikasi 4(1): 1124. 